\title{
EFFECTS OF DIFFERENT CONCENTRATIONS OF CARBOHYDRATE FORMS ON ORCHIS SANCTA L. PROPAGATION IN VITRO
}

\author{
BOZDEMIR, H. ${ }^{1}-$ ÇıĞG, A. ${ }^{*}-$ TÜRKOĞLU, N. ${ }^{2}$ \\ ${ }^{I}$ Department of Horticulture, Faculty of Agriculture, Siirt University, Siirt, Turkey \\ ${ }^{2}$ Department of Horticulture, Faculty of Agriculture, Yüzüncü Yıl University, Van, Turkey \\ *Corresponding author \\ e-mail: arzucig@yahoo.com; phone: +90-531-623-1533 \\ (Received 22 $2^{\text {nd }}$ May 2018; accepted $11^{\text {th }}$ Jul 2018)
}

\begin{abstract}
In this study, the goal was the germination and propagation of Orchis sancta L. which is endangered due to uncontrolled collection and used in obtaining salep, in vitro conditions. By the addition of 0 (control group), 20,40,60, 80, and $100 \mathrm{~g} / \mathrm{l}$ concentrations of sucrose, glucose, maltose, galactose, and fructose of carbohydrate forms into Van WaesDebergh culture medium, sugars of effects were determined on germination and development of Orchis sancta L. seeds. In the study, germination, formation of protocorm and shoot periods and ratios were examined. The highest average germination ratio was obtained as $77.85 \%$ in Maltose 40 , the lowest average as $44.36 \%$ in Galaktose100 mediums. In protocorm formation, when the highest average ratio was detected as $68.53 \%$ in Sucrose100, the lowest average as $25.33 \%$ in Fruktose100 mediums. Germination period as 12.50-21.33 days, protocorm formation period as 22.50-50.83 days and shoot formation period as 50.66-105.33 days' intervals were determined.
\end{abstract}

Keywords: culture medium, germination, orchid, protocorm, shoot

\section{Introduction}

Orchidaceae is one of the largest families of flowering plants in terms of the number of species. While the total of 150 orchid species, of which $13 \%$ being endemic, have been specified in Turkey (Erdem, 2004) that there are 117 orchid species among these are used to produce salep (Sezik, 2002). Turkey is one of the richest countries in Europe and Middle East in terms of middle zone orchids, but growing industrialization, rapid urbanization and population growth bring about social, economic and cultural imbalances. The biggest problem faced by the salep orchids, which are among the endangered and damaged plant species in the world, is the excessive uprooting of the plant because of the pharmaceutical importance of the plant drug and its commercial value particularly in the ice-cream and hot drink sector. Hatipoğlu (1981) has listed salep under bulbous-tuberous and rhizomatous ornamental plants, uprooted from natural vegetation without being propagated. According to Sezik (1984), tubers weigh 2 to $7 \mathrm{~g}$ when they are fresh. If an average of $4 \mathrm{~g}$ is considered, 250 orchids should be removed for $1 \mathrm{~kg}$ of fresh tubers. A salep collector normally can collect up to $1 \mathrm{~kg}$ of fresh tubers per day. Approximately 1000 to 4000 tubers are required for $1 \mathrm{~kg}$ of salep. İşler (2005) stated that the price of $1 \mathrm{~kg}$ of mountain salep collected and dried in Van province is 100 Turkish Liras (TL), while meadow salep is sold for 25 TL. It is known that wild collection of orchid tubers for salep production threatens orchids collected in the mountainous areas more compared to the ones collected from the meadows. With each tuber collected, next generation plant and plenty of seeds to be produced by this plant 
are prevented. According to Tekinşen (2006), 15 to 20 tonnes out of 35 to 65 tonnes of salep produced in Turkey is exported in powder from.

Due to its increasing price, powdered tubers of Muscari plant, which contains muscarinic substance which can cause harm to human health, and tubers of other plants are used as additives in salep (Hatipoğlu, 1981). The researcher emphasized in those years that heavy wild collection problem due to increasing prices is not at international level like citrus and viticulture, but is greatly a concern of Turkey. It is further mentioned that salep is not consumed in high amounts in the developed countries as in Turkey; even the foreign countries are responsive to destruction of our flora and genetic resources; and they are concerned with this issue. Glicomannan, the active substance of salep, swells with milk or water and generates a fluid solution. Thus, salep has become an essential drink in cold winter days. Additionally, salep is put into the famous Maraş ice-cream to provide late melting and hardness. Among these usages, salep has also a medical importance. It is pointed out that Avicenna (Book of Ibn Sina in C.E. 9801037) recommends the use of salep as expectorant, appetizer, anti-stroke substance and aphrodisiac (Sezik, 1984). Nonetheless, instead of being used primarily for these purposes, salep is consumed as beverage and gains economic value in ice-cream production. To attain salep, being so useful and having commercial importance, there is an irrepressible and enormous collection from the nature. Among tuberous orchids, salep is rather extracted from orchids with ovoid tuber such as Anacamptis, Orchis, Ophrys, Serapias, Himantoglossum, Barlia, and from some species with amorphous tuber such as Dactylorhiza. The harvest of every tuber prevents the plant of next year with its many seeds to grow up. Because of this uncontrolled collection, alternative production and propagation methods are aimed and constantly new techniques are developed with seeds in laboratories.

Orchis sancta L. is also an orchid species that has been collected for these purposes and is being studied to be propagated with different methods. This study aims at providing asymbiotic propagation and species continuity of Orchis sancta L., a salep orchid, in vitro conditions.

\section{Literature review}

According to Stewart and Kane (2010), the role of carbohydrates in vitro orchid seed germination and protocorm formation has received some attention, although little in recent years. In the earlier study about asymbiotic orchid seed germination, researchers realized that some carbohydrate sources were better suited to support seed germination than others, and that this response was genus- or species-specific (La Garde, 1929; Smith, 1932; Wynd, 1933). Little attention has been paid by modern researchers to the effects of carbohydrate source on asymbiotic orchid seed germination and protocorm/seedling development, and little information exists on the role of different carbohydrates in the asymbiotic germination of terrestrial orchids (Stewart and Kane, 2010).

Smreciu and Currah (1989) reported that very small orchid seeds have small testas, formed with loose and transparent cell layer and have very small embryos. Germination of orchid seeds which have limited proliferation capacities and do not contain endosperm, an appropriate mycorrhizal relation with a mycorrhizal fungus is required in the environment in addition to appropriate temperature, light, humidity and oxygen conditions (Sezik, 1984). As orchid seeds do not contain nutrient reserves, successful germination do not occur unless a carbohydrate source such as glucose is provided from 
outside (Ingold and Hudson, 1993). Adding carbohydrate to the culture medium as a germination method in addition to symbiotic germination with mycorrhiza might be successful. This way, orchid seeds' utilization of the substances in the culture medium might be changed. These alterative techniques can be tried at different stages such as germination, protocorm and shoot formation, even root and tuber formation. As a result, every study on germination and propagation and every method resulting in yield, first in the laboratory environment and then in the adaptation phase on the land, is treasured for the species continuity. Thanks to this awareness and determination, orchids will be able to seen on the ground, in their living environment.

\section{Material and methods}

\section{Seeds}

In the study, mature seeds of Orchis sancta L. species naturally grown around Aydin province in Turkey but collected and thus destroyed to obtain salep were used and 50 seeds, randomly selected before sowing, were put to Tetrazolium Chloride (TTC) viability test. The seeds soaked with distilled water in Petri dishes were kept for $12 \mathrm{~h}$ and the embryo sections were left in $1 \%$ tetrazolium chloride solution. While the pinkred coloured ones of the seeds kept at room temperature for $12 \mathrm{~h}$ are considered alive, the white-coloured ones are considered inanimate (Grabe and Peters, 1998; AOSA, 2002). According to the test results, $85 \%$ of the seeds were alive. The photos of the seeds were captured with OLYMPUS SZ61 binocular microscope dp20 camera and 10X x 1.2 software (Fig. 1).

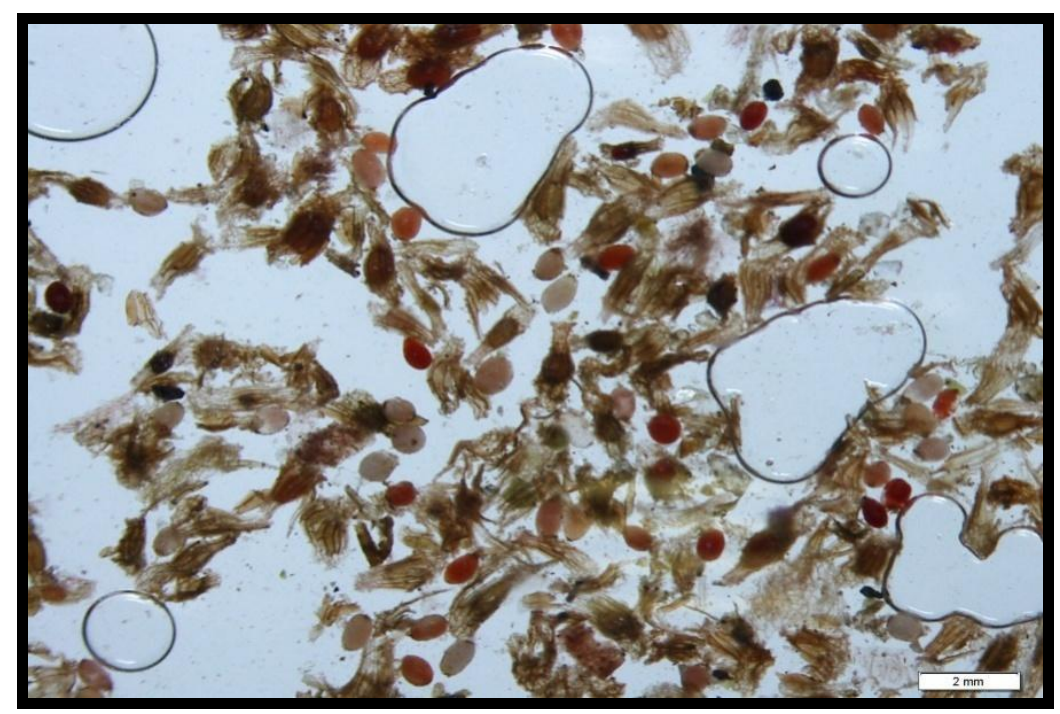

Figure 1. Aspect of Orchis sancta L. seeds under binocular microscpoe

The seeds are counted so as to sow 100 units to each Petri dish. The orchid seeds packed in coarse filter paper envelopes were sterilized for 12 min with 1-2 drops of Tween-20 and $10 \% \mathrm{NaOCl}$ and rinsed 3 times with sterile distilled water after 5 min of shaking with $2 \% \mathrm{H}_{2} \mathrm{SO}_{4}$ (Ç1 $\breve{g}$ and Y1lmaz, 2016). Sterilized seeds are sown in a total of 15 glass Petri dishes including culture media, in 3 replicates with 5 times for each replicates. 


\section{Preparation of culture medium and seed sowing}

Culture mediums were formed by adding $0,20,40,60,80$ and $100 \mathrm{~g} / 1$ concentrations of the sugar forms of sucrose, glucose, fructose, galactose and maltose into the VWD medium (Van Waes and Debergh, 1986). $0.85 \mathrm{~g} / \mathrm{l}$ agar was used for all mediums; and were autoclaved at $121{ }^{\circ} \mathrm{C}$ and 1.2 atmosphere pressure for $20 \mathrm{~min}$ after the $\mathrm{pH}$ was adjusted to 5.8 with $1 \mathrm{~N} \mathrm{HCl}$ and $1 \mathrm{~N} \mathrm{NaOH}$. The sterilized Petri dishes with sown seeds were stored in $23 \pm 1{ }^{\circ} \mathrm{C}$ and in dark place and were taken to a light/dark room for $16 / 8 \mathrm{~h}$ with the formation of protocorm. The subculturing process was repeated once a month in aseptic conditions.

\section{Statistical evaluations}

In terms of the emphasized specifications, mean and standard error are indicated with descriptive statistics. To determine any possible difference of these specifications between the concentration and culture medium, completely randomized factorial design analysis is implemented (Montgomery, 2001).

The effects model is

$$
y_{i j k}=\mu+\tau_{i}+\beta_{j}+(\tau \beta)_{i j}+e_{i j k}
$$

where, $i=1, \ldots, 6 ; j=1, \ldots, 5 ; k=1, \ldots, 90 ; \mu$ is the overall mean effect, $\tau_{i}$ is the effect of the $i^{\text {th }}$ level of concentration, $\beta_{j}$ is the effect of the $j^{\text {th }}$ level of medium, $(\tau \beta)_{i j}$ is the effect of the interaction between $\tau_{i}$ and $\beta_{j}$, and $e_{i j k}$ is a random error component.

An angular transformation is applied to the measured percent variance analysis.

$$
Y=\arcsin \theta \sqrt{p}=\sin ^{-1} \sqrt{p}
$$

Where $\mathrm{p}$ is the proportion and $\mathrm{Y}$ is the result of the transformation. The result may be expressed either in degrees or radians. The usual rule of thumb is that they should be used when there are a number of proportions close to 0 and/or close to 1 . The transformations will "stretch out" proportions that are close to 0 and 1 and "compress" proportions close to 0.5 . The amount of germination, protocorm and shoots was subjected to angular transformation and expressed in terms of their original values in (Tables 1 and 2).

Tukey Multiple Comparison test was used in determining significant difference between concentrations and carbohydrates following the variance analysis. The statistical significance level was taken as $p<0.01$ and the calculations were done with ANOVA procedure by the statistical package JMP 5.0.1a software.

\section{Results and discussions}

In the study investigating in vitro germination, protocorm and shoot formation potentials of Orchis sancta L., five different carbohydrate (sugar) forms of galactose, glucose, maltose, fructose and sucrose were added into the culture medium with 20, 40, 60, 80 and $100 \mathrm{~g} / \mathrm{l}$ concentrations (doses) were applied and differences were observed statistically with a significance level of $(\mathrm{p}<0.01)$ in the characteristics examined (Tables 1 and 2). 
Table 1. Effect of carbohydrate forms and concentrations on germination, protocorm and shoot formation rates (\%)

\begin{tabular}{|c|c|c|c|c|}
\hline $\begin{array}{l}\text { Carbohydrate } \\
\text { forms }\end{array}$ & $\begin{array}{c}\text { Carbohydrate } \\
\text { concentrations }(\mathrm{g} / \mathrm{l})\end{array}$ & $\begin{array}{c}\text { Germination } \\
\text { rate }^{* *}(\%)\end{array}$ & $\begin{array}{c}\text { Protocorm formation } \\
\text { rate }^{* * *}(\%)\end{array}$ & $\begin{array}{l}\text { Shoot formation } \\
\text { rate }^{* * *}(\%)\end{array}$ \\
\hline \multirow{6}{*}{ Galactose } & 0 & 67.53 bcdef & $55.31 \mathrm{cdefgh}$ & $0.00 \mathrm{~h}$ \\
\hline & 20 & 60.85 fghij & 59.79 bcde & $0.00 \mathrm{~h}$ \\
\hline & 40 & 59.91 ghij & 52.21 efghi & $0.00 \mathrm{~h}$ \\
\hline & 60 & 65.93 defgh & $45.90 \mathrm{ijk}$ & $0.00 \mathrm{~h}$ \\
\hline & 80 & $44.39 n$ & 31.401 & $0.00 \mathrm{~h}$ \\
\hline & 100 & $44.36 n$ & 31.791 & $0.00 \mathrm{~h}$ \\
\hline \multirow{6}{*}{ Glucose } & 0 & 67.53 bcdef & $55.31 \mathrm{cdefgh}$ & $0.00 \mathrm{~h}$ \\
\hline & 20 & 61.62 fghi & $68.44 \mathrm{a}$ & $9.02 \mathrm{c}$ \\
\hline & 40 & 66.53 cdefg & 59.86 bcde & $8.77 \mathrm{~cd}$ \\
\hline & 60 & $52.86 \mathrm{klm}$ & 46.87 hijk & $0.00 \mathrm{~h}$ \\
\hline & 80 & $47.92 \mathrm{lmn}$ & 60.34 abcde & $2.80 \mathrm{~g}$ \\
\hline & 100 & $56.39 \mathrm{ijk}$ & $41.08 \mathrm{k}$ & $0.00 \mathrm{~h}$ \\
\hline \multirow{6}{*}{ Maltose } & 0 & 67.53 bcdef & $55.31 \mathrm{cdefgh}$ & $0.00 \mathrm{~h}$ \\
\hline & 20 & $71.91 \mathrm{abcd}$ & 53.74 defghi & $0.00 \mathrm{~h}$ \\
\hline & 40 & $77.85 \mathrm{a}$ & $64.40 \mathrm{ab}$ & $0.00 \mathrm{~h}$ \\
\hline & 60 & $68.87 \mathrm{bcde}$ & 49.74 ghij & $0.00 \mathrm{~h}$ \\
\hline & 80 & 64.87 efgh & 51.22 fghij & $0.00 \mathrm{~h}$ \\
\hline & 100 & 59.73 hij & 52.66 efghi & $0.00 \mathrm{~h}$ \\
\hline \multirow{6}{*}{ Fructose } & 0 & 67.53 bcdef & $55.31 \mathrm{cdefgh}$ & $0.00 \mathrm{~h}$ \\
\hline & 20 & $72.94 \mathrm{abc}$ & 57.67 bcdefg & $13.16 \mathrm{a}$ \\
\hline & 40 & 61.18 fghij & 55.63 cdefg & $6.56 \mathrm{e}$ \\
\hline & 60 & $47.04 \mathrm{mn}$ & $43.03 \mathrm{jk}$ & $0.00 \mathrm{~h}$ \\
\hline & 80 & $50.41 \mathrm{klmn}$ & 28.941 & $0.00 \mathrm{~h}$ \\
\hline & 100 & $47.91 \mathrm{lmn}$ & 25.331 & $0.00 \mathrm{~h}$ \\
\hline \multirow{6}{*}{ Sucrose } & 0 & 67.53 bcdef & 55.31 cdefgh & $0.00 \mathrm{~h}$ \\
\hline & 20 & 68.93 bcde & $61.58 \mathrm{abcd}$ & $8.01 \mathrm{~d}$ \\
\hline & 40 & $73.88 \mathrm{ab}$ & $63.11 \mathrm{abc}$ & $13.30 \mathrm{a}$ \\
\hline & 60 & 63.28 efgh & 58.72 bcdef & $5.36 \mathrm{f}$ \\
\hline & 80 & $54.62 \mathrm{jkl}$ & 50.52 fghij & $3.50 \mathrm{~g}$ \\
\hline & 100 & 66.25 cdefgh & $68.53 \mathrm{a}$ & $10.90 \mathrm{~d}$ \\
\hline
\end{tabular}

**In the same column, the difference between the averages indicated by the same letter is insignificant at level $\mathrm{p}<0.01$

\section{Germination rate of the seeds (\%)}

While germination occurred in all mediums and doses, it was observed that the highest germination average is obtained from Maltoz40 with $77.85 \%$ (Table 1). The lowest average value of germination is obtained from the Galactose 100 medium with 44.36\%. Taking into consideration all sugar forms in general, it appears that germination rates decrease as the used doses increasing. This suggests that the 
increasing of sugar concentration has a reducing effect on the germination of $O$. sancta seeds (Figs. 2 and 3).

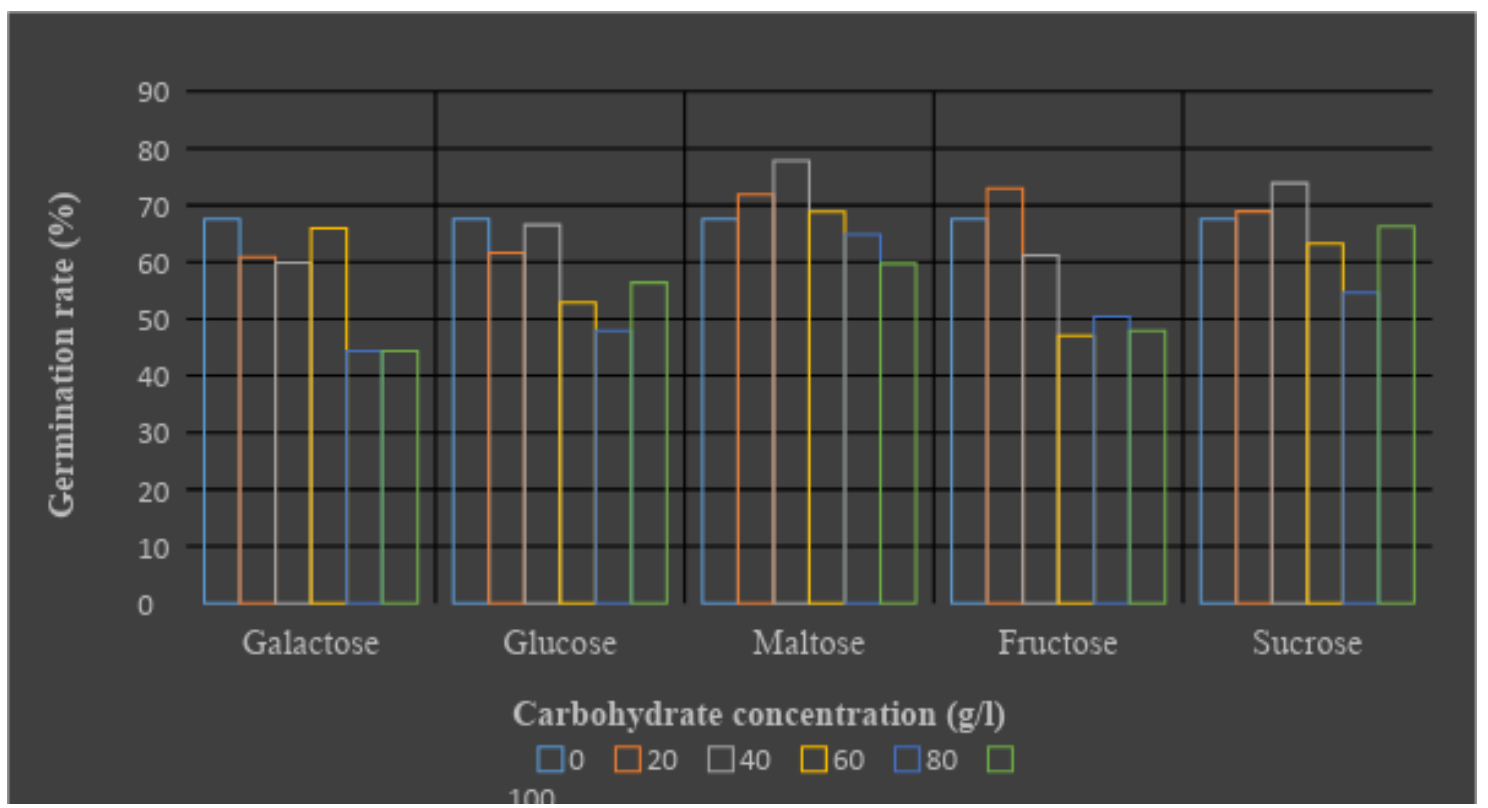

Figure 2. Effects of carbohydrate forms and concentrations on germination rates (\%)

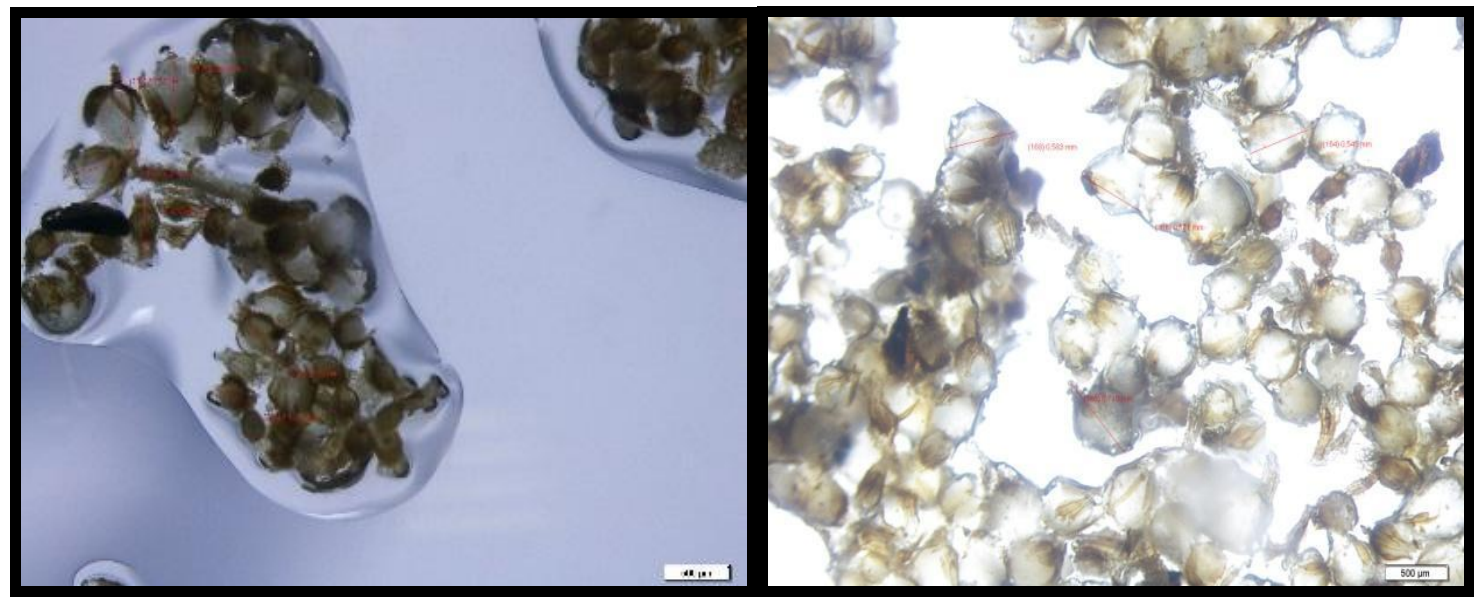

Figure 3. Germinated O. sancta seeds in culture medium

In vitro asymbiotic germination of orchid seeds, some inorganic substances and sucrose, glucose and other sugars are useful for the culture medium; dextrose and sucrose can also be used as sugar sources (Harvais, 1973). In our study, sucrose and glucose were sugars that had an effect on germination after maltose. Van Waes and Debergh (1986) reported that sucrose is more effective on germination compared to other sugars, and mentioned a negative effect of galactose. Galactose has the lowest germination rate in our study. Mead and Bulard (1975), succeeded in adding sucrose in their study with species of Orchis and Ophrys genus. In another study on Dactylorhiza species, it is reported that germination was stimulated through glucose and sucrose (Wotavová-Novotná et al., 2007). Considering previous studies, it can be concluded that 
glucose and sucrose induce germination at the most. In our study, these two types of sugar have the highest second and third mean values following maltose (Fig. 2). It is presumed that the culture medium and orchid species used by the researchers may be different. Culture mediums used in germination studies on rather different species vary as well. This study of $O$. sancta species has the highest percentage of germination under maltose impact in the VWD medium.

In a study with nine orchid species, in which three of them generated positive results, the germination rate of $O$. sancta was found $100 \%$ (Önal, 1999). Yet in another study, $20 \%$ sugar was added to 1/10 MS (Murashige \& Skoog) medium and ultrasonication was applied to germinate the seeds; and the Orchis italica seeds were germination with the rate of $81 \%$ (Yararbaş, 2008). $30 \mathrm{~g} / 1$ of sucrose was added during the study with 6 orchid species executed in full strength MS, VWD and KC (Knudson-C) mediums and $1 / 2$ MS medium. A germination rate of $7.34 \%$, which is the highest, occurred in VWD medium (Gümüş et al., 2008). In the study with O. sancta seeds, KC and VWD mediums with added $\mathrm{GA}_{3}$, BAP, coconut milk, banana and potato extract was used and the germination rate was found as $20-40 \%$ in VWD medium and $20-100 \%$ in KC medium Sar1 et al. (2011). Bulunuz Palaz et al. (2012) has found the highest germination rate among five orchid species as $30 \%$ for the $O$. sancta species. In another study of the researchers, $O$. sancta seeds showed a germination rate of $79.08 \%$ in EBP + AC (activated charcoal) medium (Bulunuz Palaz et al., 2014).

\section{Protocorm formation rate (\%)}

The protocorm phase is described as the formation of a nail-like structure after germination (Sezik, 2002), and the protocorm amount is obtained by calculating percentage ratios to germinated seeds. Again in $60 \mathrm{~g} / \mathrm{l}$ and above applications of sugar concentrations used in parallel with germination, decreasing mean values were obtained. Protocorm formed in all applied mediums and doses (Fig. 4) and the highest protocorm formation rate was obtained from Sucrose100 with $68.53 \%$ (Table 1). The lowest protocorm mean value was obtained from Fructose 100 medium with the rate of $25.33 \%$. Taking into account all sugar forms in general, protocorm ratios decreases with increasing doses. However, the $60 \mathrm{~g} / \mathrm{l}$ dose seems to be a breaking point and then the protocorm formation increases again in general (Fig. 5).

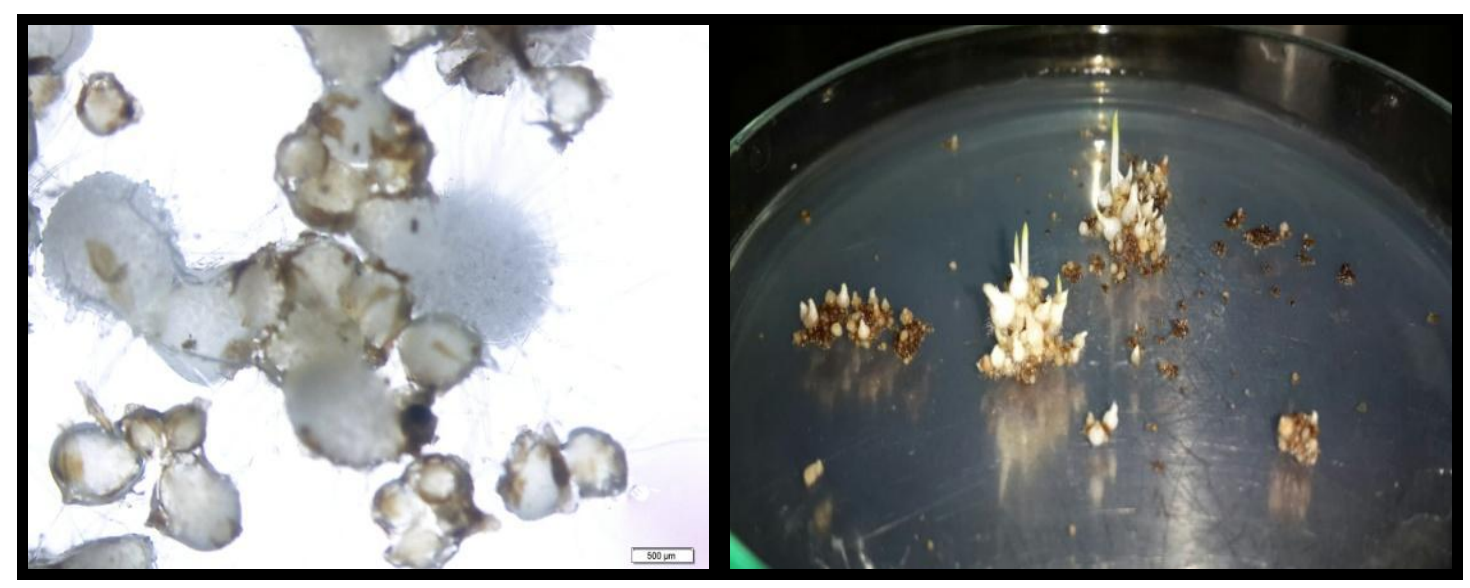

Figure 4. Protocorm formation in germinated $O$. sancta seeds in culture medium 


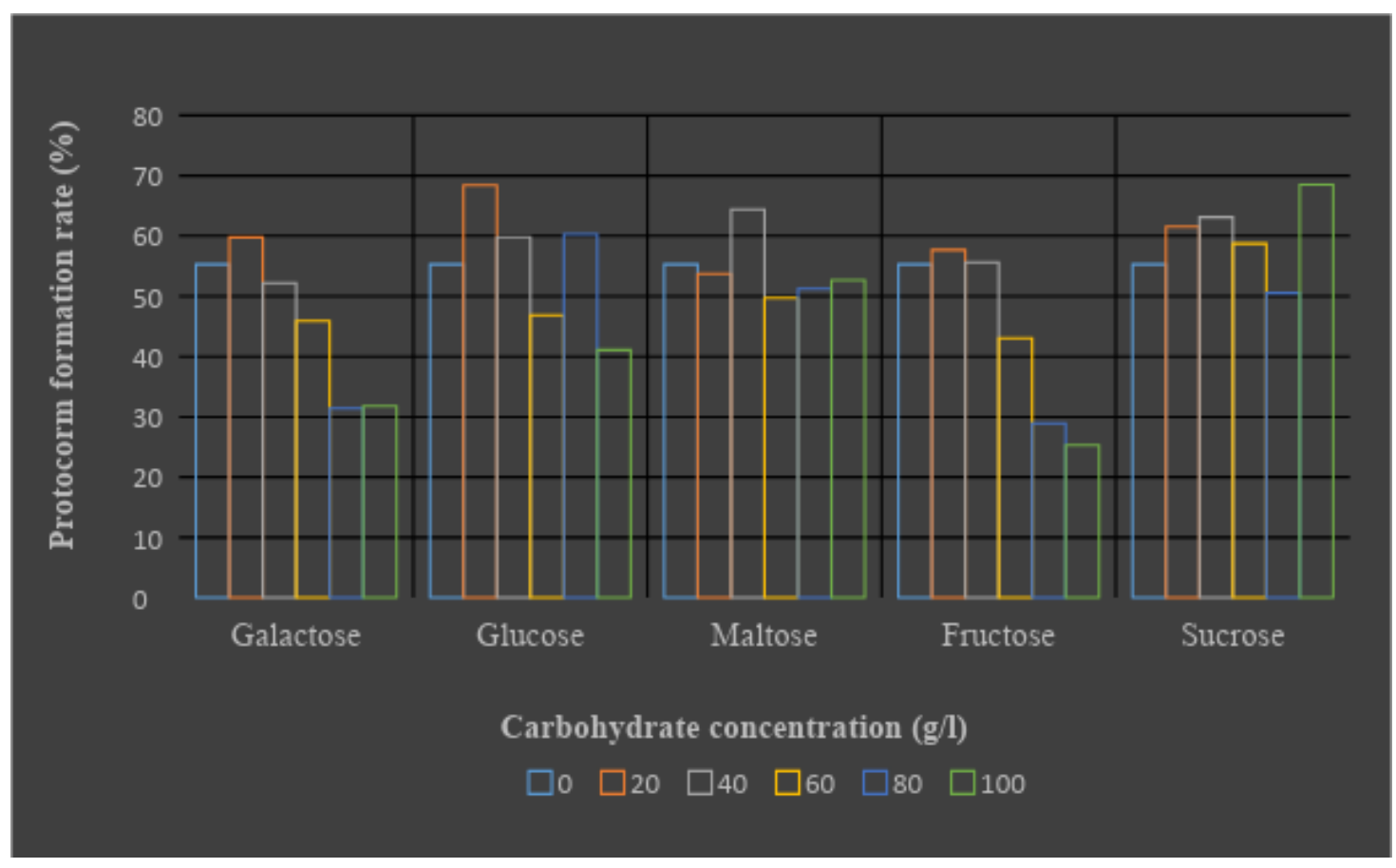

Figure 5. Effects of carbohydrate forms and concentrations on protocorm formation rates (\%)

The highest rate of protocorm formation for six orchid species was 13.11\% (Gümüş et al., 2008). The highest protocorm formation in six orchid species, germinated in five different culture mediums, has been obtained in KC and VWD mediums with a rate of $62.92 \%$ (Çı̆ and Y1lmaz, 2016). In the study using $\mathrm{KC}$ and $\mathrm{KC}+1 \mathrm{mg} / \mathrm{l} \mathrm{GA} 3$ mediums for cultivation, protocorm formation occurred in $5.34 \%$ of $O$. sancta species which is the highest among the five orchid species (Bulunuz Palaz et al., 2012). In an in vitro study on eight orchid species, O. sancta seeds have formed $78.12 \%$ protocorm in $\mathrm{EBP}+\mathrm{AC}$ medium (Bulunuz Palaz et al., 2014). In an in vitro study on five orchid species, the highest rate of protocorm formation occurred in a medium including tripton; recorded $28 \%$ for Serapias vomeracea species, $48 \%$ for $O$. sancta species and $48 \%$ for Orchis coriophora species (Karakuş, 2015).

As we can conclude from similar studies, protocorm generally showed successful development in VWD mediums. It is thought that especially the rate of $78.12 \%$ mean value obtained from $O$. sancta is a result of the $\mathrm{EBP}+\mathrm{AC}$ medium. A protocorm formation rate of $5.34 \%$ was obtained from $\mathrm{KC}+1 \mathrm{mg} / \mathrm{l} \mathrm{GA}$ medium, but despite it contained hormones, this was considerably below the mean value occurred in our study. The effect of culture medium on the protocorm formation of $O$. sancta species is obvious.

\section{Shoot development rate (\%)}

Shoot development did not occur in all mediums and concentrations (Fig. 6). In some doses of glucose and fructose; and in all doses of sucrose, shoot development was observed. Shoots were developed with the rate of $0-9.02 \%$ in the glucose group; 0$13.16 \%$ in the fructose application and 3.50-13.30\% in the sucrose application.

The sucrose application was an effective sugar in protocorm formation, while it had the same effect also in shoot development. Likewise, glucose was also a sugar type that 
followed sucrose; nonetheless, while fructose had a lower performance in protocorm formation compared to other sugar types, it showed a more positive effect on shoot development (Fig. 7).

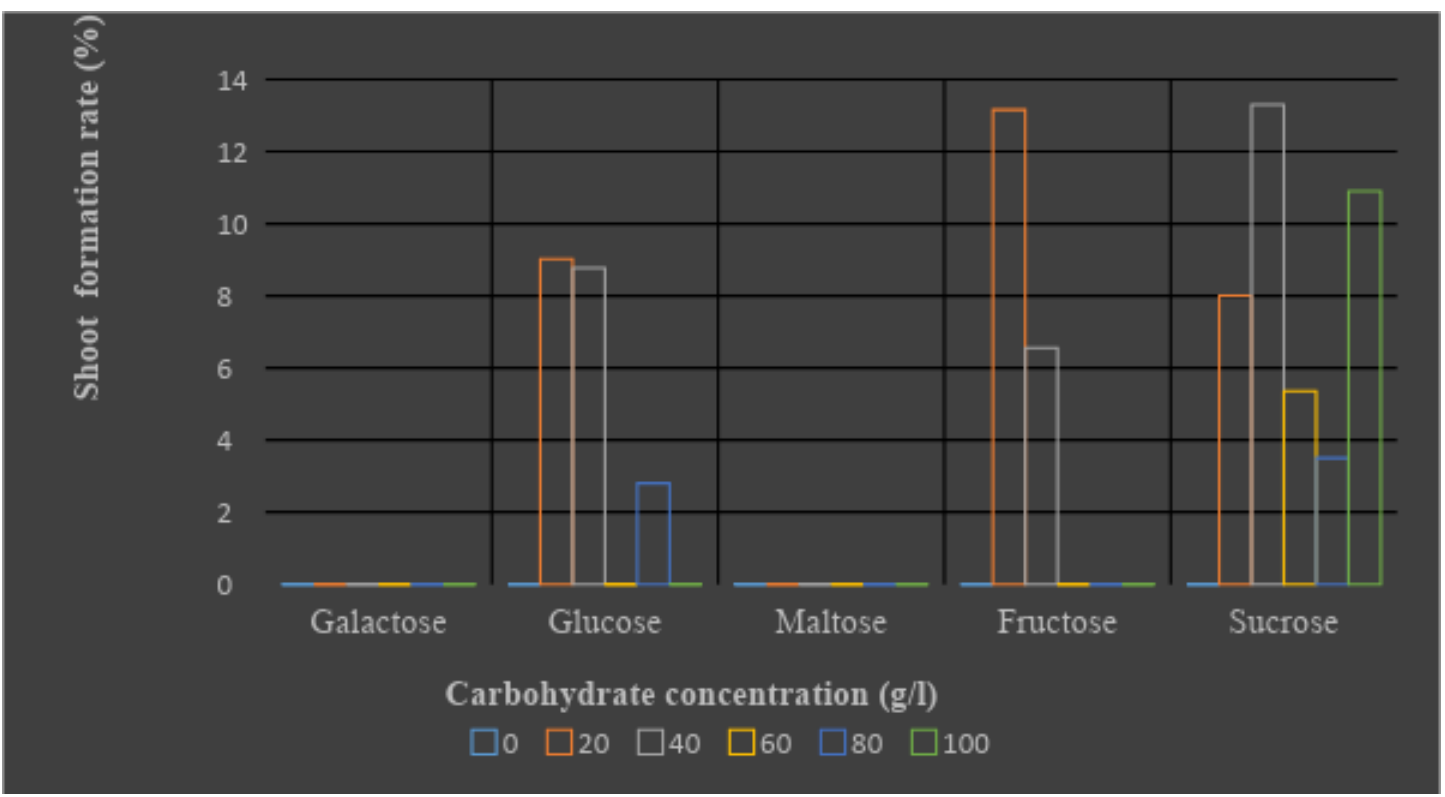

Figure 6. Effects of carbohydrate forms and concentrations on shoot formation rates (\%)

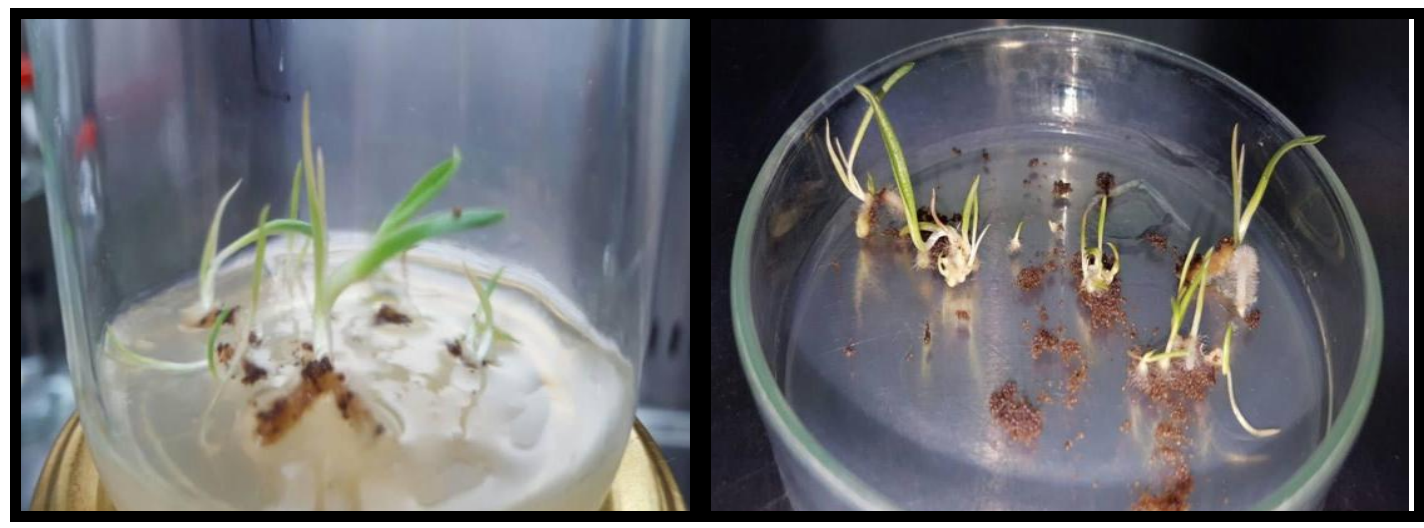

Figure 7. Developed O. sancta shoots in culture medium

On the other hand, maltose and galactose exhibited a negative effect on shoot development, while having positive effects on protocorm formation. It is reported that sucrose has the most positive effect among sugars used for germination and development (Van Waes and Debergh, 1986); and that glucose, glucose, mannose, maltotriose and maltopentaose can be used for seedlings cultivated from in vitro applications (Ernst and Arditti, 1990). In all phases of O. sancta seeds, from germination to shoot development, the negative effect of galactose is observed. On the contrary, glucose and sucrose had a stimulating role in all the levels of the study.

In previous research, the amounts of plantlets stemming from protocorm were obtained with rates of $1.86 \%$ (Çağlayan et al., 1998) and 80\% (Önal, 1999). The highest 
shoot development rates obtained from protocorm was observed in $\mathrm{KC}$ medium, MS and 1/10 MS mediums (Çı̆ and Y1lmaz, 2016). In the study with five orchid species applied in two culture mediums, the highest plant development rate determined as $3.5 \%$ in O. sancta (Bulunuz Palaz et al., 2012). In the study with 8 orchid species, O. sancta seeds had a shoot development at the rate of $72.50 \%$ in $\mathrm{EBP}+\mathrm{AC}$ medium (Bulunuz Palaz et al., 2014).

\section{Germination period (day)}

The highest germination period was obtained in Galactose 80 as 21.33 days; while the lowest period was 12.50 days in Glucose40, Maltose40 and Sucrose20 (Table 2). Considering the mediums separately in terms of germination period, the average values were 14.66-21.33 days in the galactose application; 12.50-15.83 days in the glucose application; 12.50-15.33 days in the maltose application; 13.16-20.83 days in the fructose application and 12.50-15.33 days in the sucrose application (Fig. 8).

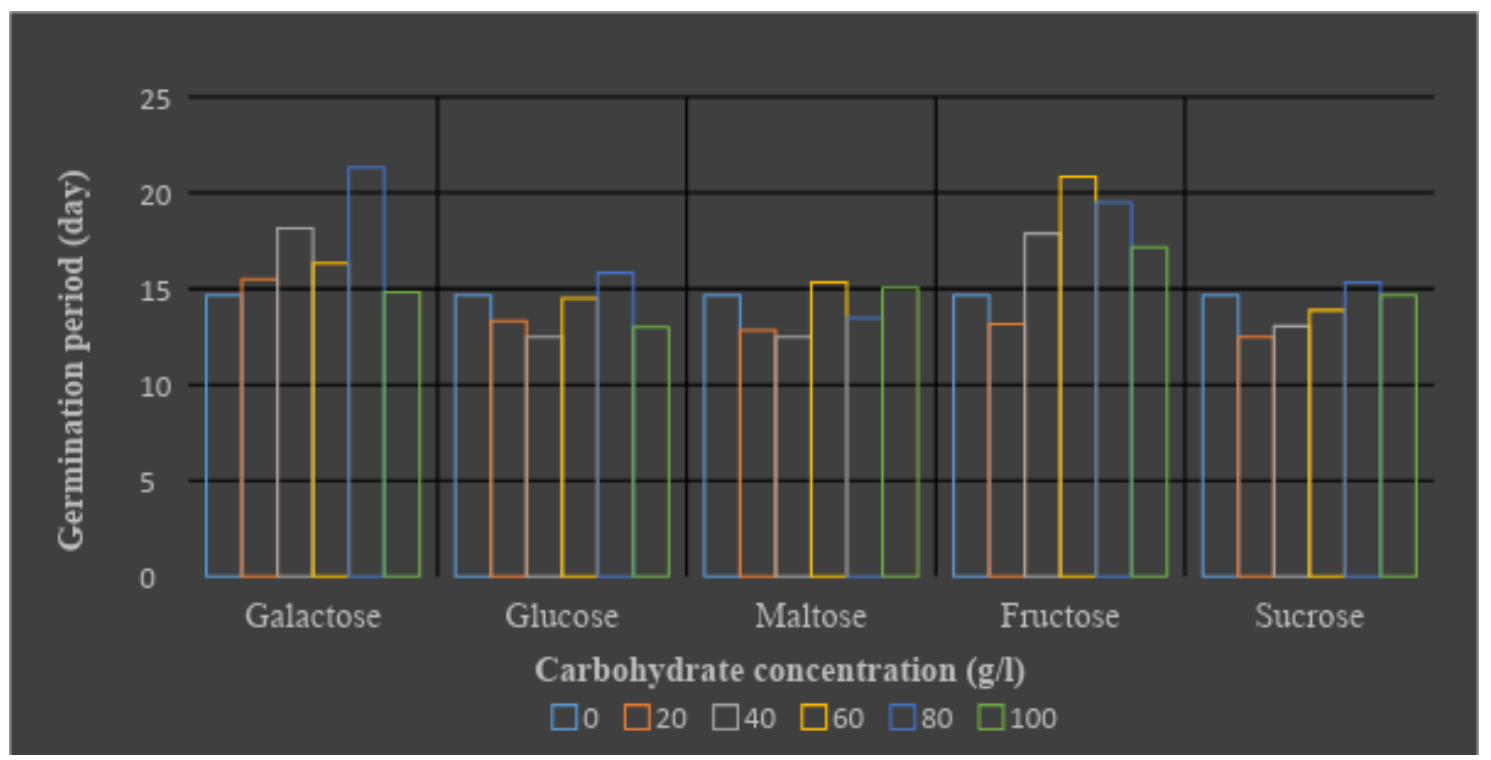

Figure 8. Effects of carbohydrate forms and concentrations on germination periods (days)

Germination of seeds cultivated in vitro conditions was observed in 58 days in orchid seeds (Çăglayan et al., 1998), and in15 days in Orchis italica seeds (Yararbaş, 2008). In a study with $O$. sancta and other seed species, the earliest germination was observed in O. sancta seeds after a month (Önal, 1999); and after two weeks in another study (Bulunuz Palaz et al., 2012). In a study with Modified Lucke (LM), MS, Lindemann, Vacin \& Went, Malmgren Modified (MM) and KC mediums; BAI, Zea, Kin, 2-iP cytokinins and 0/24, 16/8, 24/0 light/dark photoperiods, the Habenaria macroceratitis terrestrial orchid seeds showed the highest germination rate of approximately $89 \%$ in $\mathrm{LM}$ and $\mathrm{KC}$ mediums at the $7^{\text {th }}$ week of the study (Stewart and Kane, 2006). In another study, cracking and decolourization were observed in cultivated seeds in 15-20 days (Sar1 et al., 2011). The germination period of 4 orchid species cultivated in KC, VWD and Pfeffer nutrient mediums was observed as 3 months (Kısakürek, 2011). In a study to identify the effects of VWD, KC, MS, $1 / 2$ MS and 1/10 MS culture mediums on the germination period of orchid seeds; the effect of VWD medium on germination 
appeared in the range of 27.67-130.53 days (Çı̆̆ and Y1lmaz, 2016). Considering the other mediums, this range was 22.00-191 days.

Table 2. Effects of carbohydrate forms and concentrations on germination, protocorm and shoot development periods (day)

\begin{tabular}{|c|c|c|c|c|}
\hline $\begin{array}{l}\text { Carbohydrate } \\
\text { forms }\end{array}$ & $\begin{array}{c}\text { Carbohydrate } \\
\text { concentrations }^{* * *}(\mathrm{~g} / \mathrm{l})\end{array}$ & $\begin{array}{l}\text { Germination } \\
\text { period** (day) }^{*} \text { (da) }\end{array}$ & $\begin{array}{c}\text { Protocorm } \\
\text { formation period }^{* *} \\
\text { (day) }\end{array}$ & $\begin{array}{c}\text { Shoot } \\
\text { development } \\
\text { period }^{* *} \text { (day) }\end{array}$ \\
\hline \multirow{6}{*}{ Galactose } & 0 & 14.66 fghij & $23.66 \mathrm{gh}$ & $0.00 \mathrm{~g}$ \\
\hline & 20 & 15.50 defghi & $22.50 \mathrm{~h}$ & $0.00 \mathrm{~g}$ \\
\hline & 40 & $18.16 \mathrm{bcd}$ & $34.66 \mathrm{~cd}$ & $0.00 \mathrm{~g}$ \\
\hline & 60 & $16.33 \mathrm{defg}$ & $25.83 \mathrm{efgh}$ & $0.00 \mathrm{~g}$ \\
\hline & 80 & $21.33 \mathrm{a}$ & $51.33 \mathrm{a}$ & $0.00 \mathrm{~g}$ \\
\hline & 100 & 14.83 fghij & $24.50 \mathrm{gh}$ & $0.00 \mathrm{~g}$ \\
\hline \multirow{6}{*}{ Glucose } & 0 & 14.66 fghij & $23.66 \mathrm{gh}$ & $0.00 \mathrm{~g}$ \\
\hline & 20 & $13.33 \mathrm{hij}$ & $22.83 \mathrm{~h}$ & $89.33 \mathrm{c}$ \\
\hline & 40 & $12.50 \mathrm{j}$ & $25.83 \mathrm{efgh}$ & $100.66 \mathrm{ab}$ \\
\hline & 60 & 14.50 fghij & $31.83 \mathrm{def}$ & $0.00 \mathrm{~g}$ \\
\hline & 80 & 15.83 defgh & $32.66 \mathrm{de}$ & $75.66 \mathrm{~d}$ \\
\hline & 100 & $13.00 \mathrm{hij}$ & $25.00 \mathrm{fgh}$ & $0.00 \mathrm{~g}$ \\
\hline \multirow{6}{*}{ Maltose } & 0 & 14.66 fghij & $23.66 \mathrm{gh}$ & $0.00 \mathrm{~g}$ \\
\hline & 20 & $12.83 \mathrm{ij}$ & $25.00 \mathrm{fgh}$ & $0.00 \mathrm{~g}$ \\
\hline & 40 & $12.50 \mathrm{j}$ & $25.66 \mathrm{fgh}$ & $0.00 \mathrm{~g}$ \\
\hline & 60 & 15.33 defghij & $30.50 \mathrm{defg}$ & $0.00 \mathrm{~g}$ \\
\hline & 80 & 13.49 ghij & $25.60 \mathrm{fgh}$ & $0.00 \mathrm{~g}$ \\
\hline & 100 & 15.05 efghij & $27.66 \mathrm{efgh}$ & $0.00 \mathrm{~g}$ \\
\hline \multirow{6}{*}{ Fructose } & 0 & 14.66 fghij & $23.66 \mathrm{gh}$ & $0.00 \mathrm{~g}$ \\
\hline & 20 & 13.16 hij & $27.16 \mathrm{efgh}$ & $99.33 \mathrm{~b}$ \\
\hline & 40 & 17.88 bcde & $40.72 \mathrm{bc}$ & $105.33 \mathrm{a}$ \\
\hline & 60 & $20.83 \mathrm{~b}$ & $50.83 \mathrm{a}$ & $0.00 \mathrm{~g}$ \\
\hline & 80 & $19.50 \mathrm{abc}$ & $43.66 \mathrm{~b}$ & $0.00 \mathrm{~g}$ \\
\hline & 100 & $17.16 \mathrm{cdef}$ & $39.66 \mathrm{bc}$ & $0.00 \mathrm{~g}$ \\
\hline \multirow{6}{*}{ Sucrose } & 0 & 14.66 fghij & $23.66 \mathrm{gh}$ & $0.00 \mathrm{~g}$ \\
\hline & 20 & $12.50 \mathrm{j}$ & $25.00 \mathrm{fgh}$ & $60.66 \mathrm{e}$ \\
\hline & 40 & $13.05 \mathrm{hij}$ & $24.33 \mathrm{gh}$ & $50.66 \mathrm{f}$ \\
\hline & 60 & 13.88 ghij & 28.38 defgh & $101.16 \mathrm{ab}$ \\
\hline & 80 & 15.33 defghij & 28.00 defgh & $57.99 \mathrm{e}$ \\
\hline & 100 & 14.66 fghij & 28.88 defgh & $104.50 \mathrm{a}$ \\
\hline
\end{tabular}

**In the same column, the difference between the averages indicated by the same is insignificant at $\mathrm{p}<0.01$

According to the studies, the germination period varied in terms of species with diverse mediums and applications (15-191 days). However, in this study, getting close results to those obtained in the previous in vitro study, specifying the germination periods of 1 month and 2 weeks especially with $O$. sancta species, reveals the early 
germination period of the seeds of $O$. sancta species. It is believed that the added carbohydrate and its concentrations of the culture medium were effective.

\section{Protocorm formation period (day)}

While glucose, maltose and sucrose applications showed the earliest effect on germination, the mediums with the earliest results in protocorm formation were identified as maltose, sucrose and galactose (Table 2). Despite the highest protocorm formation period was obtained from Galactose 80 with 51.33 days, the difference with the value of 50.83 days obtained from Fructose60 was considered statistically insignificant. The lowest protocorm formation period averages were obtained from Galactose20 as 22.50 days and Glucose20 as 22.83 days (Fig. 9).

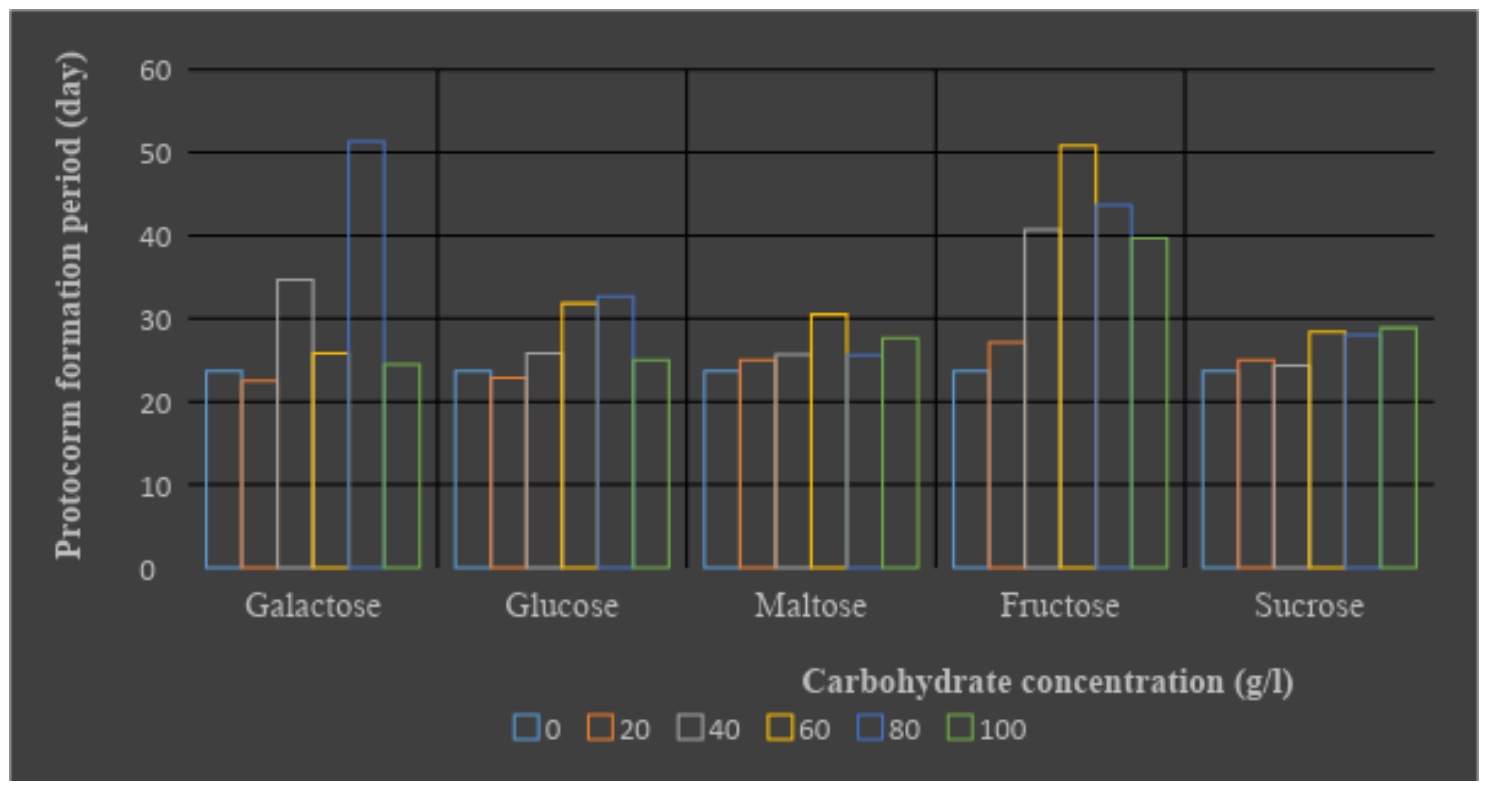

Figure 9. Effects of carbohydrate forms and concentrations on protocorm formation periods (days)

Protocorm was obtained in two months in the seeds of Orchis lutea and Orchis fusca, cultivated in modified Curtis medium (Barroso et al., 1990). Examining the effects of different nutrient mediums, plant growth regulators and light/dark applications on the protocorm formation of Habenaria macroceratitis terrestrial orchid, protocorm development was observed in MM medium between 7 and 16 weeks (Stewart and Kane, 2006). In studies utilizing bioreactors, protocorm formation was obtained in 8 weeks (Paek et al., 2001; Young et al., 2000); and in 40 days (Yang et al., 2010) after sowing. In a study, no further development occurred during 8 months after sowing seeds, but protocorm formation was observed after this period by adding $2 \mathrm{mg} / \mathrm{l}$ IAA to the nutrient medium (Sar1 et al., 2011). As protocorm formation periods ranged between 53.50-309.94 days when all mediums are considered, the periods in VWD medium were 58.50-309.94 days (Çı̆ and Yılmaz, 2016). In a study to follow the germination and protocorm formation of Orchis sancta, which is shown among endangered species, full strength and $1 / 2$ strength Lindemann (LDM) medium containing $20 \mathrm{~g} / 1$ sucrose and $7 \mathrm{~g} / 1$ agar was used and protocorm formation was observed in the $12^{\text {th }}$ week (Acemi et al., 2013). 
Comparing the protocorm formation period of $O$. sancta in this study and the period of the previous one, it is clear that success was achieved in a considerably short time. The protocorm formation range in other studies appears as 40-309.94 days. It is inferred that this period varies in association with the cultivated plant species and medium contents

\section{Shoot development period (day)}

The highest shoot development period was obtained from Fructose 40 with 105.33 days and Sucrose100 with 104.50 days (Table 2). The lowest average shoot development period was obtained from Sucrose40 with 50.66 days (Fig. 10). Besides, shoot development was not observed in all the galactose and maltose applications; in 0 , $60,100 \mathrm{~g} / \mathrm{l}$ doses of glucose; $0,60,80$ and $100 \mathrm{~g} / \mathrm{l}$ doses of fructose and $0 \mathrm{~g} / \mathrm{l}$ dose of sucrose, and therefore, shoot development periods could not be recorded.

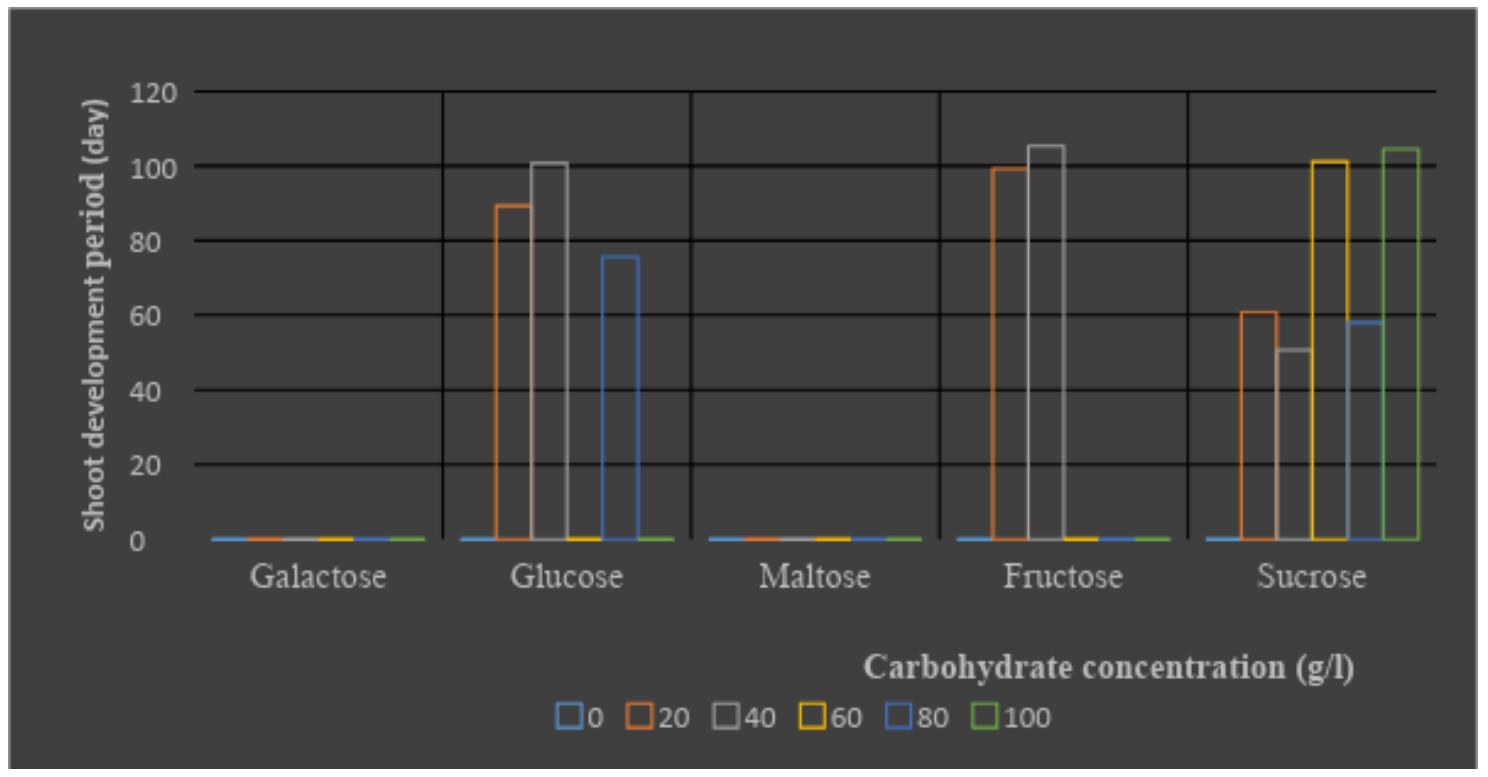

Figure 10. Effects of carbohydrate forms and concentrations on shoot development periods (day)

Shoot tips of Orchis mascula seeds cultivated in six different nutrient mediums has occurred in 4-5 months (Valetta et al., 2008). The first leaves developed from Orchis italica seeds after 2 months (Yararbaş, 2008).

Taking into account the effect of five different culture mediums on shoot development periods, the range of 79.00-406.83 days is noticeable; while the earliest shoot development in VWD medium was 95.33 days, and the latest shoot development emerged in 267.78 days (Çı̆ and Y1lmaz, 2016). In a study testing three orchid species, it was found that sucrose, glucose and fructose were the best energy sources for the Oeceocladesde caryana species. It is reported that shoots of Dactylorhiza majalis developed slightly weak in fructose, and very weak in glucose (Ponert et al., 2011). These studies indicate that hexoses are not a good carbohydrates source for these species. Ophrys lojaconoi exhibited better development in sucrose, weak in glucose, and very week in fructose. Many protocorms have developed better in fructose containing mediums but could not grow further. This proved that fructose has an 
inhibitive effect in the protocorm development. It is reported that sucrose is used more for in vitro orchids but that fructose and glucose are also used (Michl, 1988; Rasmussen, 1995).

Since orchid seeds do not have endosperms, carbohydrate supplement is required to initiate germination. As with the type of carbohydrate, its concentration added in the culture medium is also important. That is because the stimulating role of sugar can be inhibitive in some doses. This study reveals that the sugar types and their concentrations have different effects in germination, protocorm and shoot development phases of $O$. sancta seeds.

\section{Conclusions}

As a result, in vitro germination of the $O$. sancta species, the best performances were achieved from maltose, and then sucrose among five sugar types used in the study. Sucrose was the most effective sugar type for protocorm formation. In shoot development, the first sugar with performance was fructose, then sucrose and glucose at last. It is thought that maltose can be used in the germination of $O$. sancta or other orchid species; and sucrose in the protocorm and shoot development. Applications specific for each species as well as general adaptations might be possible. For O. sancta, maltose in germination, sucrose in protocorm formation; fructose in shoot development; and as sugar concentrations, doses such as 0,20 and $40 \mathrm{~g} / \mathrm{l}$ in germination; 20 and $40 \mathrm{~g} / \mathrm{l}$ in protocorm; $100 \mathrm{~g} / \mathrm{l}$ in shoot development can be used. Hence, it is understood that low concentrations for germination and protocorm formation can be used, while high doses should be avoided. The applications in this study to be suggested for the use of sugar and doses together might be: Maltoz40 for germination; Glucose20 and Sucrose20 for protocorm; Furctose 20 and Sucrose40 for shoot development.

Acknowledgements. This paper is derived from the master's thesis supported by project Nr. SïU-FEB-25 of Siirt University Coordinator of Scientific Research and Projects.

\section{REFERENCES}

[1] Acemi, A., Kuran, R., Özen, F. (2013): In vitro Germination and Protocorm Formation of a Naturally Growing Salep Orchid in Turkey, Orchis sancta. - Workshop Abstracts Book, 5th International Orchid Workshop.

[2] AOSA (2002): Seed Vigor Testing Hand Book. Contribution No. 32. - Association of Official Seed Analysts, New Mexico.

[3] Barroso, J., Fevereiro, P., Oliviera, M. M., Pais, M. S. S. (1990): In vitro seed germination, differentiation and production of mini tubers from Ophrys lutea Cav., Ophrys fusca Link and Ophrys speculum Link. - Scientia Horticulturae 42(4): 329-337.

[4] Bulunuz Palaz, E., Özdemir, A., Kaya, Y. (2012): Bazı salep orkide türlerine ait tohumların asimbiyotik çimlendirilmesi üzerine yapılan araştırmalar. - Türkiye 2. Orkide ve Salep Çalıştayı Bildirileri, 25-26 Nisan 2012, İzmir, pp. 293-300.

[5] Bulunuz Palaz, E., Kaya, Y., Özdemir, A. (2014): Some sahlep orchids seeds in vitro germination and shoot development. - International Mesopotamia Agriculture Congress, 22-25 September 2014, Diyarbakır, Turkey, pp. 154-163.

[6] Çağlayan, K., Özavcı, A., Eskalen, A. (1998): Doğu Akdeniz Bölgesi’nde yaygın olarak yetişen bazı salep orkidelerinin embriyo kültürü kullanılarak in vitro koşullarda çoğaltılması. - Turkish J. Agriculture and Forestr. 22: 187-195. 
[7] Çı̆̆, A., Yılmaz, H. (2016): Determination of in vitro Plantlet of Some Terrestrial Orchid Species. Development in Science and Engineering, Chapter 3. - St. Kliment Ohridski University Press Sofia, Bulgaria, pp. 29-40.

[8] Erdem, H. E. (2004): Biyolojik Çeşitliliğinin Ekonomik Değerinin Belirlenmesi, Yabani Orkide Örneği. - Ms. Thesis, E. Ü., Fen Bilimleri Ens., İzmir.

[9] Ernst, R., Arditti, J. (1990): Carbohydrate physiology of orchid seedlings, III. Hydrolysis of maltooligo saccharides by Phalaenopsis (Orchidaceae) seedlings. - Amer J Bot 77(2): 188-195.

[10] Grabe, D. F., Peters, J. A. (1998): Lactic Acid clearing of grass seeds in tetrazolium tests. - Seed Technol 20(1): 106-108.

[11] Gümüş, C., Sezik, E., Ellialtıoğlu, Ş. (2008): Batı Karadeniz Bölgesi’nde yetişen ve salep elde edilen bazı orkide (Orchidaceae sp.) türlerinin doku kültürü ile çoğaltılması üzerinde bir araştırma. - III. Ulusal Süs Bitkileri Kongresi. 8-10 Kasım 2006, İzmir, pp. 179-187.

[12] Harvais, G. (1973): Growth requirements and development of Cypripedium reginae in axenic culture. - Can. J. Bot. 51: 327-332.

[13] Harvais, G. (1982): An improved culture medium for growing the orchid Cypripedium reginaeaxenically. - Can. J. Bot. 60(12): 2547-2555.

[14] Hatipoğlu, A. (1981): Soğanl, yumrulu ve rizomlu süsbitkileri, yetiştiriciliği ve sorunları. - Akdeniz Bölgesi Bahçe Bitkileri Yetiştiriciliğinde Sorunlar, Çözüm Yolları ve Yapılması Gereken Araştırma Simpozyumu. 9-13 Nisan, İncekum, Alanya, pp. 942-976.

[15] Ingold, C. T., Hudson, H. J. (1993): The Biology of Fungi. Sixth Ed. - Chapman Hall, London.

[16] İşler, S., 2005. Van Salebinin Menşei ve Van Civarının Orkideleri. - Doctorate Thesis. Yüzüncü Y1l Üniversitesi Fen Bilimleri Ens., Van.

[17] Karakuş, B. (2015): Bazı salep orkidelerinin in vitro ortamda çimlenme, protokorm ve bitkicik oluşumunu etkileyen faktörleri araştırılması. - Ms. Thesis. Sütçü İmam Üniversitesi Fen Bilimleri Ens., Kahramanmaraş.

[18] Kısakürek, Ş. (2011): Kahramanmaraş florasında bulunan salep orkidelerinin kültüre alınabilme olanakları. - I. Salep Orkidesi Çalıştayı. 24-25 Mayıs, Kahramanmaraş, pp. 23-38.

[19] Mead, J. W., Bulard, C. (1975): Effects of vitamins and nitrogen sources on asymbiotic germination and development of Orchis laxiflora and Ophrys sphegodes. - New Phytologist 74(1): 33-40.

[20] Michl, J. (1988): Standardizovaná metoda množení evropských orchidejí semeny II. Živa 3: 89-91.

[21] Montgomery, D. C. (2001): Design and Analysis of Experiments. - John Wiley \& Sons, New York.

[22] Önal, K. (1999): Ege Bölgesi'nde doğal yayılışgösteren Orchidaceae familyasına ait bazı türlerin in vitro koşullarda üretimleri üzerinde araştırmalar. - Turkish Agriculture and Forestry 23(5): 1057-1064.

[23] Paek, K. Y., Hahn, E. J., Son, S. H. (2001): Application of bioreactors for large-scale micropropangation system of plants. - In Vitro Cellular \& Developmental Biology Plant 37(2): 149-157.

[24] Ponert, J., Vosolsobě, S., Kmecová, K., Lipavská, H. (2011): European orchid cultivation-from seed to mature plant. - European Journal of Environmental Sciences 1(2): 95-107.

[25] Rasmussen, H. N. (1995): Terrestrial Orchids, from Seed to Mycotrophic Plant. Cambridge University Press, Cambridge.

[26] Sar1, A. O., Tutar, M., Çiçek, F. (2011): Ege Tarımsal Araştırma Enstitüsü salep üretim çalışmaları. - I. Salep Orkidesi Çalıştayı. 24-25 Mayıs, Kahramanmaraş, pp. 65-86.

[27] Sezik, E. (1984): Orkidelerimiz, Türkiye'nin Orkideleri. - Sandoz Kültür Yayınları 6: 166. 
[28] Sezik, E. (2002): Turkish orchids and salep. - Acta Pharmaceutica Turcica. 44: 151-157.

[29] Smreciu, E. A., Currah, R. S. (1989): Symbiotic germination of seeds of terrestrial orchids of North America and Europe. - Lindleyana 1(4): 6-16.

[30] Stewart, S. L., Kane, M. E. (2006): Asymbiotic seed germination and in vitro seedling development of Habenaria macroceratitis (Orchidaceae), a rare Florida terrestrial orchid. - Plant Cell, Tissue and Organ Culture 86(2): 147-158.

[31] Tekinşen, K. K. (2006): Salep. - Bilim ve Teknik (453): 76-77.

[32] Valletta, A., Attore, F., Bruno, F., Pasqua, G. (2008): In vitro asymbiotic germination of Orchis mascula L. - Plant Biosystems 142(3): 653-655.

[33] Van Waes, J. M., Debergh, P. C. (1986): In vitro germination of some Western European orchids. - Physiol Plant 67(2): 253-261.

[34] Wotavová-Novotná, K., Vejsadová, H., Kindlmann, P. (2007): Effect of sugars and growth regulators on in vitro growth of Dactylorhiza species. - Biologia Plantarum 51(1): 198-200.

[35] Yang, J. F., Piao, X. C., Sun, D., Lian, M. L. (2010): Production of protocorm-like bodies with bioreactor and regeneration in vitro of Oncidium 'Sugar Sweet'. - Scientia Horticulture 125(4): 712-717.

[36] Yararbaş, R. T. (2008): Bazı Orkide Türlerinin in Vitro Koşullarda Çoğaltılması, Çiçeklenmesi. - Doctorate Thesis, E. Ü., Fen Bilimleri Enstitüsü, Bornova, İzmir.

[37] Young, P. S., Murthy, H. N., Paek, K. Y. (2000): Mass multiplication of protocorm-like bodies using bioreactor system and subsequent plant regeneration in Phalaenopsis. Plant Cell Tis. Organ Cul. 63(1): 67-72. 